\title{
Investigating the effect of weather on punctuality of Norwegian railways: a case study of the Nordland Line
}

\author{
Ghazal Zakeri $^{1} \cdot$ Nils O. E. Olsson ${ }^{1}$ (i)
}

Received: 14 February 2018/Revised: 3 June 2018/Accepted: 5 June 2018/Published online: 29 June 2018

(C) The Author(s) 2018

\begin{abstract}
The overall punctuality of the railway system is of particular importance for customers in order to use trains as a means of public transport. Investigating the drivers of low punctuality of trains is an essential step for improving their punctuality. Severe weather conditions are assumed to be one of the drivers of delays and low punctuality of the transportation system. This paper addresses the extent to which the weather factors such as temperature, snow, precipitation and wind influence the punctuality of trains on the Norwegian railways. The data for the study are collected from the passenger trains on the Nordland Line. The study period is 10 years, from the beginning of 2007 to the end of 2016. Data are analysed on a daily and weekly basis, and correlation and regression analyses are used to perform the statistical analysis. The results show that extreme cold weather during the winters is a crucial influencing factor contributing to delays and low punctuality. We also found that the weather variable that best explains variations in punctuality of passenger trains on this line is snow depth.
\end{abstract}

Keywords Punctuality analysis · Railway · Delays · Weather factors

Nils O. E. Olsson

nils.olsson@ntnu.no

1 Norwegian University of Science and Technology, 7491 Trondheim, Norway

\section{Introduction}

According to several studies, the punctuality of railway systems positively affects satisfaction of railway customers [1-3]. Therefore, improvement in punctuality is necessary in order to maintain the success and competitiveness of railway companies [4]. The Norwegian government has the vision to expand the role of railway transportation and is currently working on shifting the transportation from road to rail through improving its competitiveness. The Norwegian railway has aimed to keep the punctuality of its railway transportation system above $90 \%$. This target has been met for passenger trains since 2012 in general. However, suburban trains in the greater Oslo area, which carry the majority of travellers, and passenger trains on the Nordland Line, which is the longest railway line in Norway, have not been able to meet the target. Neither has freight train services. ${ }^{1}$

If the Norwegian railways are to achieve this for all railway lines in the coming decades, the services of passenger transportation, operational stability and punctuality of the railway system must be improved. However, severe weather conditions and climate changes are among hazards that cause delays and low punctuality of the transportation system.

Research on how weather influences train traffic may be divided into three streams of research. One stream is focused on the effects of temporary extreme weather conditions, such as snowstorms. Studies of winter conditions in Europe in 2009 and 2010 are of this category (see, for example, [5]). Earlier examples include the storm that occurred on 16 October 1987 in England [6]. This has traditionally been a major focus in studies related to

\footnotetext{
${ }^{1}$ http://www.banenor.no/Nyheter/punktlighet.
} 
weather and railway traffic. A second stream of research addresses climate change and how that affects the railway system (including [7, 8]). A third stream of research addresses how weather influences railway traffic performance in general. Such studies not only focus on extreme weather situations, but aim at analysing data for a range of weather conditions (typically for a defined time period). This study mainly belongs to this third stream of research.

The purpose of this research is to examine the role of a number of weather parameters on the performance of the railway system in terms of punctuality. The area of study chosen for this research is the Nordland railway line in Norway. The main reason for selecting this case is that the line has the potential to give us a better picture of the impact of severe regular weather conditions on the transportation system. Winter conditions that would be regarded as exceptional in major parts of Europe, including most other parts of Scandinavia, are normal on this line. We therefore get the chance of studying 'extreme' weather on a regular basis. From a railway practitioner's perspective, these conditions are predictable and the public expect that a railway operation in this part of the country can manage such conditions.

The rest of the paper is organized as follows: Sect. 1.1 defines the terms punctuality and delay, and Sect. 1.2 gives a brief overview of the characteristics of the Norwegian railway and its punctuality over a period of 10 years (2006-2015). Section 2 presents previous studies which investigated the influence of weather factors on train delays and punctuality. Section 3 presents the method of the study including data and data analysis. The results of the study are presented and discussed in Sect. 4, and conclusions are drawn in Sect. 5.

\subsection{Punctuality and delay}

Punctuality is a quality factor and an indicator of time performance in the railway context $[9,10]$. Punctuality and delays are often used interchangeably, but there are differences between these two terms. Hansen [11] defines punctuality as 'the percentage of trains passing, arriving or departing at given locations of the railway network no later than a certain time in minutes'. With similar connotation, train punctuality is measured as the percentage of trains arriving at/departing from stations within a predefined deviation from the timetable [10, 12, 13]. This predefined time deviation varies in different countries and for different modes of transport. In Norway, the margin for local trains is $3 \mathrm{~min}$ and $59 \mathrm{~s}$, and for long-distance trains, it is $5 \mathrm{~min}$ and $59 \mathrm{~s}$. Trains delayed by less than a predefined deviation are counted as punctual. The punctuality level can be measured at different points on the train's route where the arrival or departure time is recorded. Delays are represented in time units [14].

Another measurement is used to indicate causes of registered delays on the way to the final destination. If the delay increases by 4 min or more between two measuring points, the cause of the delay must be registered. The delay registration is undertaken by the train dispatcher or traffic controller [15]. The accumulation of these delays is summarized as the delay hours. It is important to note that a train may accumulate a number of delays along its way, but punctually reach the final destination. This means that the train has compensated for the accumulated delays through utilizing slack in the timetable [14].

\subsection{Characteristics and punctuality of Norwegian railways}

Rail transport in Norway consists of a network with a total of $4087 \mathrm{~km}$ of railway lines across the northern and southern parts of the country, of which $60 \mathrm{~km}$ are highspeed lines, $2622 \mathrm{~km}$ are electrified lines, and $242 \mathrm{~km}$ are double track. The Norwegian railway network includes 2760 bridges and 696 tunnels.

Figure 1 illustrates the Norwegian railway network with its major destinations. Main tracks for long-distance freight and regional trains are single-track lines. The current number of double-track lines in the network is relatively low $(6 \%)$, and almost all of them are placed in the larger Oslo area. New double-track lines are being constructed across the country.

We are particularly interested in the study of data from the Nordland Line. This section is marked in green in Fig. 1. The Nordland Line is the longest railway line in Norway $(729 \mathrm{~km})$ and runs through areas with various weather characteristics, from coastlines to high mountains. Moreover, it is one of the regions exposed to the lowest temperatures in Norway. Therefore, it has the potential to give us a better picture of the possible influence of severe weather conditions on the transportation system. The Nordland Line connects Trondheim Central Station to Bodø Station and serves the most populous area of the Trøndelag county and parts of the county of Nordland. The line runs through most cities and urban areas along this corridor, including Trondheim Airport, Værnes, Steinkjer, Mosjøen, Mo i Rana, and Fauske, and is therefore heavily used. The Nordland railway network includes 300 bridges, 155 tunnels, 690 level crossing and 42 passenger traffic stations [16]. The Nordland Line is not electrified, and only the southern part of the line, from Trondheim to south of Mosjøen, is equipped with automatic train control, while over half of the line is managed manually. Areas served by the Nordland Line have the highest rail market share for freight transportation in Norway. 


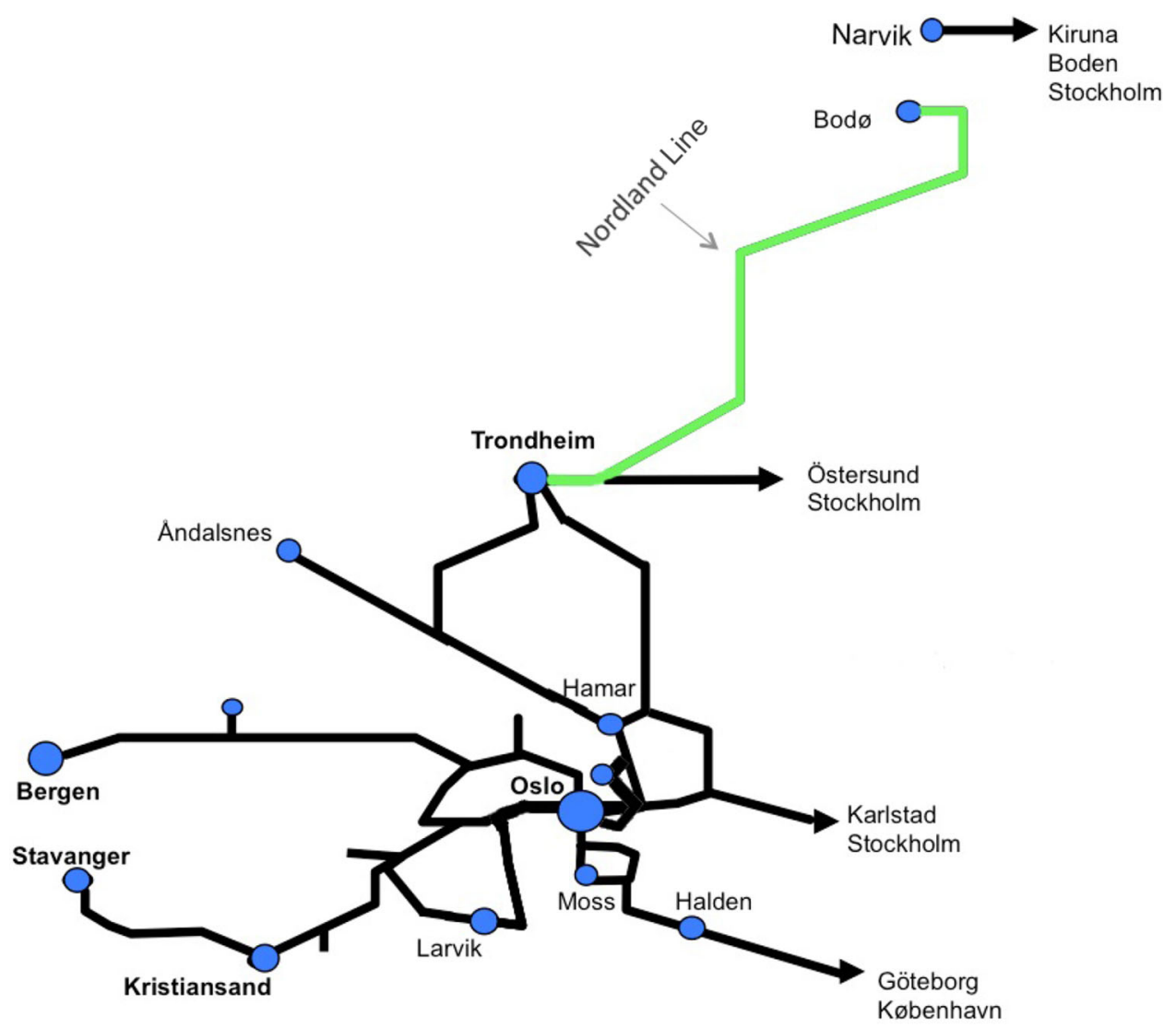

Fig. 1 Norwegian railway network

The Nordland Line is exposed to challenging and varying climatic and operational conditions. It reaches its highest elevation of $680 \mathrm{~m}$ above mean sea level at about the same location as it crosses the Arctic Circle. In addition to the management of climate-related conditions, winter also causes problems related to collisions with large animals, in particular with elks and reindeer, both of which are common along this line. In winter, they prefer to stay on the railway line, as the snow is cleared here and it is easier to move there compared to the surrounding snow-covered areas.

Figure 2 illustrates the performance of different train services in terms of annual punctuality for a period of 10 years since 2006 in Norwegian railways. The figure shows that Norwegian railways experienced a steady decline in punctuality over a period of 5 years (2006-2010), and the overall punctuality has improved since 2010.

The focus of this paper is on determining the effect of weather conditions on the punctuality of passenger trains.

\section{Previous research on weather and punctuality of railway network}

Although the majority of the literature had originally studied the effects of weather on transport in the road sector, much focus has recently also been placed on the study of the effects of weather on rail transport. In this section, a review of weather-related studies of railway traffic is presented first. The studies in both categories are sorted from the newest to the oldest. We then focus on the Norwegian railway and how this study is related to recent punctuality research in Norway.

Brazil et al. [17] studied the effect of weather conditions on the Dublin Area Rapid Transit rail system and observed that rain is the main factor resulting in delays on a metropolitan rail service. Diab and Amer [18] studied the effect of snow and rain on delays of Toronto subways and concluded that the delays are considerably higher on the outdoor tracks, particularly during the winter season. Palmqvist et al. [19] found that punctuality for Swedish trains falls exponentially as the temperature drops below $0{ }^{\circ} \mathrm{C}$. At $-5{ }^{\circ} \mathrm{C}$ the punctuality was about $7.5 \%$-points lower than average, and at $-30{ }^{\circ} \mathrm{C}$, it was about $50 \%$ - 


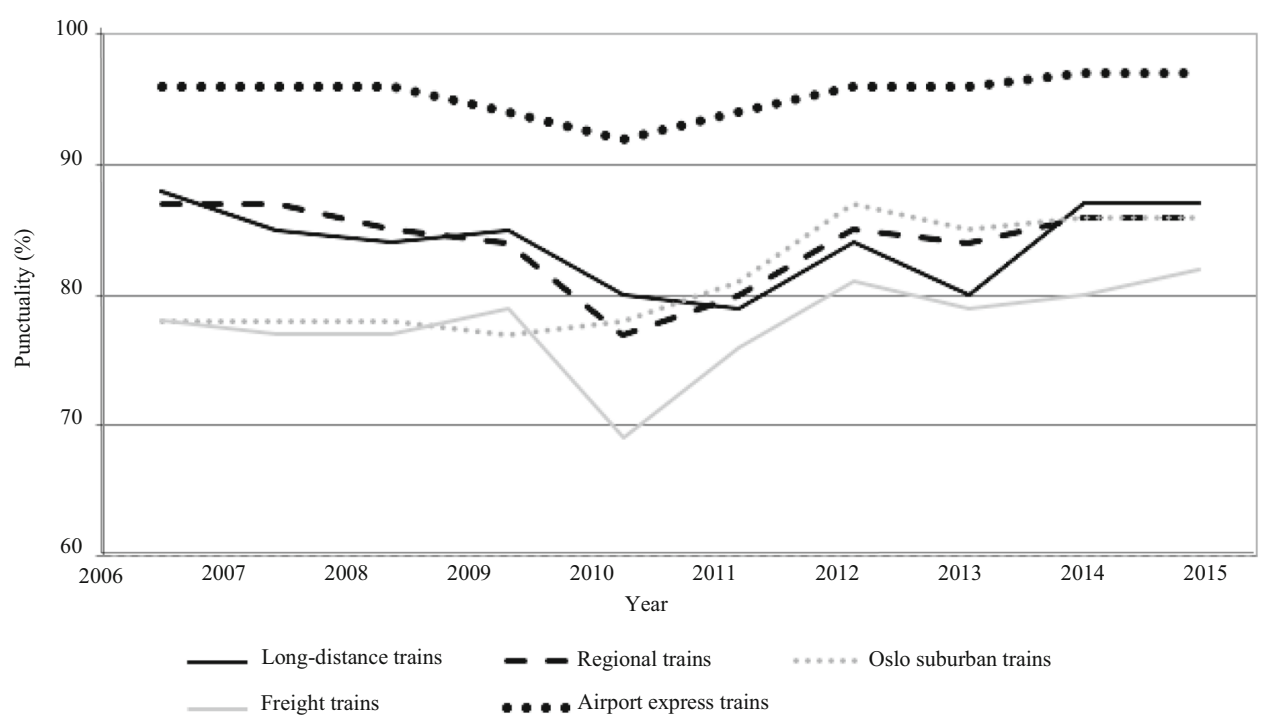

Fig. 2 Punctuality trend of different train services. Data source: Jernbaneverket [16]

points lower than average punctuality. $\mathrm{Xu}$ et al. [20] studied the probability and impacts of different disruption sources on Chinese high-speed railways and described that bad weather has an impact on delayed traffic. Nagy and Csiszar [21] analysed delay causes in Hungarian railway passenger transportation and found that extreme cold or hot weather contributes to delays of trains. The study by Jaroszweski et al. [22] used delay and timing data from UK road and rail network and explored how the intense storm incident caused the failure of infrastructure, knock-on delays and widespread disruption. Mesbah et al. [23] showed that rainfall and air temperature can play a significant role in the performance of the Melbourne tram system in terms of travel time.

Ludvigsen and Klaboe [5] estimated the effect of the extreme winter weather in 2010 on freight railways in Norway, Sweden, Switzerland and Poland. Their results show that bad weather and/or weather-related technical damage to the network was the main reasons for $60 \%$ of all delayed arrivals. They showed that 'rail operators were totally unprepared to deal with the powerful and cascading effects of three harsh weather elements-long spells of low temperatures, heavy snow depths and strong winds-which affected them concurrently and shut down large swathes of European rail infrastructure and train operations'.

Xia et al. [24] studied the effect of weather conditions on the performance of the train operator in the Dutch railway network. They found that wind, snow, precipitation, temperature and leaves contribute to infrastructure disruptions and showed that punctuality and cancellation rates are negatively impacted due to disturbances in railway infrastructure. The study by Tsapakis et al. [25] focused on how rain, snow and temperature levels affect travel times in the transport network of London. They found that heavy rain and heavy snow result in travel time increases of up to $6 \%$ and $11.4 \%$, respectively, while temperature has almost negligible effects on travel times.

Juntti [26] studied the impact of weather (temperature, precipitation and wind) on railway operation in a rail section in Sweden. The results of the study showed that snow and ice have more effect on railway failures than rain and wind in the studied area. Another study in Sweden of the same year was conducted by Stenström et al. [27]. They investigated the impact of cold climate on failures in railway infrastructure by comparing two Swedish lines, one in the very north part of the country and one in the very south. Their results showed that there are more failures in the winter time than in summer time in both regions. However, the winters in the northern line have more effect on railway operations than in the southern line.

Although most of the research on investigating the impact of weather on railway operation is conducted after 2010, a few studies also existed before 2010. A study by Thornes and Davis [28] showed that approximately $20 \%$ of annual unplanned delay minutes, a delay that is related to a failure of the infrastructure, on the UK rail network are attributable to adverse weather conditions. One of the earliest studies goes back to 1987 when Johnson [6] investigated the effect of wind on British railway operations. However, the study was not a correlational study and it only made a detailed examination of the extreme wind conditions for the storm that occurred on the morning of 16 October 1987 in the south-east of England. The Swedish Riksrevisionsverket [29] found that monthly average 
temperatures below $-5{ }^{\circ} \mathrm{C}$ reduced the punctuality, roughly by $5 \%$ points for each centigrade of average monthly temperature below $-5{ }^{\circ} \mathrm{C}$.

When it comes to Norway, this study is part of a larger research effort to improve punctuality analytics in Norwegian railways and to identify actions for punctuality improvements. The larger ongoing research collaboration has developed tools to utilizing railway punctuality data for identification of improvement actions [15]. A toolkit for analysis and a handbook have been developed. The tools visualizations and analysis were first implemented as a prototype and then transferred to the Norwegian Railway Authority. The visualizations support identification of punctuality improvement measures. This paper represents a deeper analysis of weather-related parameters, to provide a compliment to the more visual-based analyses that are supported by the toolkit.

The mentioned research efforts include some studies investigating the influence of weather factors on punctuality in rail transport. Tahvili [30] described how cold temperatures during winters are problematic for the railroad. However, their study is rather descriptive, whereas our current research uses statistical analysis to study the correlation between weather factors and railway performance and considers more weather variables. Bettez [31] studied winter operations and different technologies that can be used in order to cope with winter problems and to increase the efficiency of the infrastructure network during Norway's long and cold winters. Another study has been done by Olsson et al. [32] in which they reported that one of the causes of the negative trend of punctuality of Norwegian railways in the period 2005-2010 was the inability to handle normal variation in the weather. Our study focuses on a longer period (2007-2016), considers more weather variables and uses a higher-resolution dataset.

In our previous research [33], we investigated the relationship between two weather factors (temperature and snow depth) and the punctuality of trains in the Oslo area for the period 2007-2010 using a weekly dataset. Our results showed that there is a strong correlation between very cold days, days with temperature below $-15^{\circ} \mathrm{C}$ and/ or snow depth above $30 \mathrm{~cm}$, and the punctuality of local trains. In the study of [33] for local urban trains there was a stronger correlation between poor punctuality and low temperature than between poor punctuality and deep snow. In this paper, we intend to quantify the impact of more weather variables (temperature, snow depth, precipitation and wind speed) and to cover a broader time span (2007-2016) by using a more granular dataset (including daily measurements).

\section{Method}

In this section, we first present the data and overview of the variables used in this research and then describe how the data are analysed.

\subsection{Data}

The data for this study were collected for the Nordland Line (Trondheim-Bodø) for passenger trains bound for Bod $\varnothing$ (indicated by green in Fig. 1). The study period is 10 years, from the beginning of 2007 to the end of 2016 .

We used two sources of data for the purposes of this research which can be categorized as:

- Traffic data including aggregated punctuality or total number of departure punctuality. This is a collocated measurement that shows the overall quality of the railway system delivery.

- Weather data including historical daily meteorological observations of temperature, snow depth, wind speed and precipitation in Norway.

The traffic data used in the study are provided by Bane NOR (previously known as Jernbaneverket), Norwegian government's agency for railway services. We only considered the punctuality of passenger trains which completed the journeys. Freight trains and fully or partially cancelled trains were not included. The data were collected with the resolution of per day. We calculated punctuality as the percentage of trains departing from stations with a delay not exceeding 4 min between the actual and scheduled departure times. The range of punctuality on a single day was between $0 \%$ and $100 \%$. In the case of using weekly or monthly data rather than daily data, the average of daily punctuality was calculated per week and month. We ended up to 2088 and 14,608 punctuality observations for the weekly and daily datasets, respectively.

Historical weather data were obtained from eKlima [34], a web-based portal providing access to the climate database of the Norwegian Meteorological Institute. Weather data were measured per day per weather station, although data for some days were missing. We extracted data from twelve weather stations across the Trondheim-Bodø line for which measurements were available. Figure 3 shows the location of the Nordland railway line and meteorological stations.

We selected four categories of weather variables: temperature, snow depth, precipitation and wind speed. The variables were chosen based on their possible effect on punctuality (from previous studies) and the availability of data. In the case of using weekly or monthly data rather 


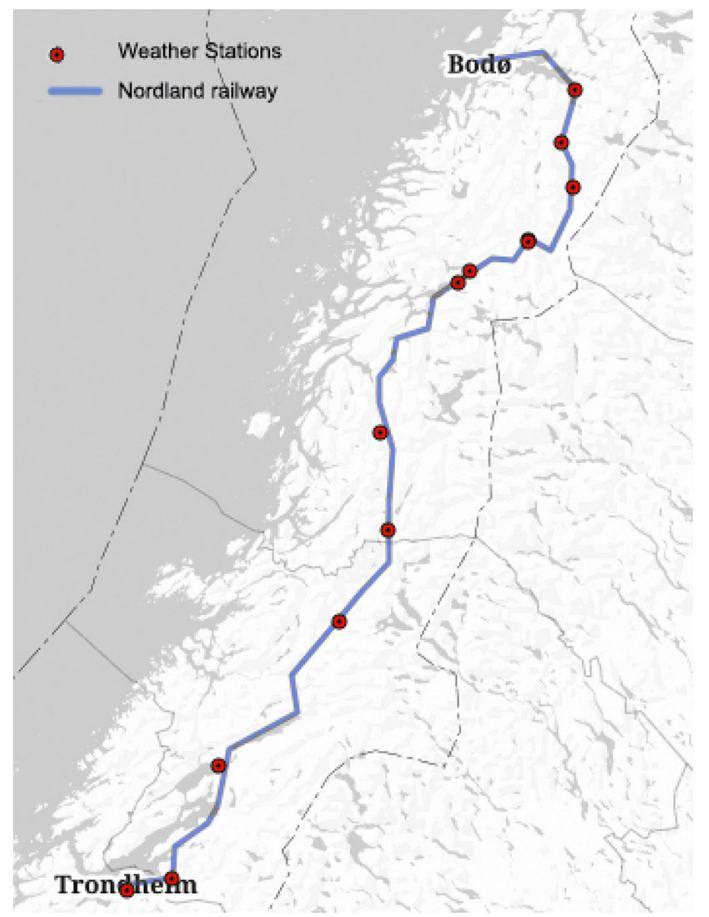

Fig. 3 Nordland railway line and weather stations selected for the main analysis (Source for map: Google Maps, www.google.com/ maps)

than daily data, the average of daily weather data was calculated per week and month. An overview of variables used for the analyses is given in Table 1.

\subsection{Data analysis}

The analysis was performed using descriptive statistics including graphical evaluations, paired samples $t$ test, correlation and regression analysis. The data were analysed using $R$.

First, we plotted the average punctuality of passenger trains in the Nordland railway line during winter versus other seasons, as shown in Fig. 4. We defined the winter season from the beginning of November until the end of the following March. In general, it is observed that punctuality is lower in winter than in the other seasons.

Figure 5 shows the average monthly punctuality of passenger trains in the Nordland railway line. The punctuality records demonstrate a noticeable slippage during the winter months in the period 2007-2014. We can also see that it took longer for the average monthly punctuality during winters to reach its normal levels. Additionally, we plotted the number of days in a month with a low temperature over the period 2007-2016, as shown in Fig. 6. The concurrence of a high number of extremely cold days and days with low punctuality performance in some winters may reveal the existence of a correlation between cold weather and low punctuality which needs to be tested for its significance. We performed a $t$ test to see whether the average of punctuality is different in winters compared to the other seasons using daily, weekly and monthly datasets. It was found that this difference is statistically significant with a $p$ value approaching 0 .

Table 1 Overview of variables, punctuality and weather

\begin{tabular}{|c|c|c|c|c|}
\hline Variable & Indicator name & Description of indicator & Unit & Data source \\
\hline Punctuality & $\begin{array}{l}\text { Punctuality of } \\
\text { passenger trains }\end{array}$ & $\begin{array}{l}\text { Daily and weekly punctuality for local passenger } \\
\text { trains }\end{array}$ & $\begin{array}{l}\text { Percentage of trains } \\
\text { departing on time }\end{array}$ & $\begin{array}{l}\text { Departure time } \\
\text { registrations }\end{array}$ \\
\hline \multicolumn{5}{|l|}{ Weather } \\
\hline \multirow[t]{2}{*}{ Temperature } & $\begin{array}{l}\text { Minimum } \\
\text { temperature }\end{array}$ & Minimum temperature across the journey & ${ }^{\circ} \mathrm{C}$ & Weather data \\
\hline & $\begin{array}{l}\text { Temperature below } \\
\quad-15^{\circ} \mathrm{C}\end{array}$ & $\begin{array}{l}\text { Days with temperature below }-15^{\circ} \mathrm{C} \text { during } \\
1 \text { week }\end{array}$ & Number of days & Weather data \\
\hline \multirow[t]{3}{*}{ Snow depth } & $\begin{array}{l}\text { Maximum snow } \\
\text { depth }\end{array}$ & Maximum snow depth across the journey & $\mathrm{cm}$ & Weather data \\
\hline & $\begin{array}{l}\text { Snow depth above } \\
30 \mathrm{~cm}\end{array}$ & Days with snow depth above $30 \mathrm{~cm}$ during 1 week & Number of days & Weather data \\
\hline & Sum of snow depth & $\begin{array}{l}\text { Sum of all snow depths recorded at several stations } \\
\text { across the journey }\end{array}$ & $\mathrm{cm}$ & Weather data \\
\hline \multirow[t]{2}{*}{ Precipitation } & $\begin{array}{l}\text { Maximum } \\
\text { precipitation }\end{array}$ & Maximum precipitation across the journey & $\mathrm{mm}$ & Weather data \\
\hline & $\begin{array}{l}\text { Precipitation above } \\
\qquad 10 \mathrm{~mm}\end{array}$ & $\begin{array}{l}\text { Days with precipitation above } 10 \mathrm{~mm} \text { during } \\
1 \text { week across the journey }\end{array}$ & $\mathrm{mm}$ & Weather data \\
\hline \multirow[t]{2}{*}{ Wind speed } & $\begin{array}{l}\text { Maximum wind } \\
\text { speed }\end{array}$ & Maximum wind speed across the journey & $\mathrm{m} / \mathrm{s}$ & Weather data \\
\hline & $\begin{array}{l}\text { Wind speed above } \\
10 \mathrm{~m} / \mathrm{s}\end{array}$ & $\begin{array}{l}\text { Days with wind speed above } 10 \mathrm{~m} / \mathrm{s} \text { during } 1 \text { week } \\
\text { across the journey }\end{array}$ & $\mathrm{m} / \mathrm{s}$ & Weather data \\
\hline
\end{tabular}




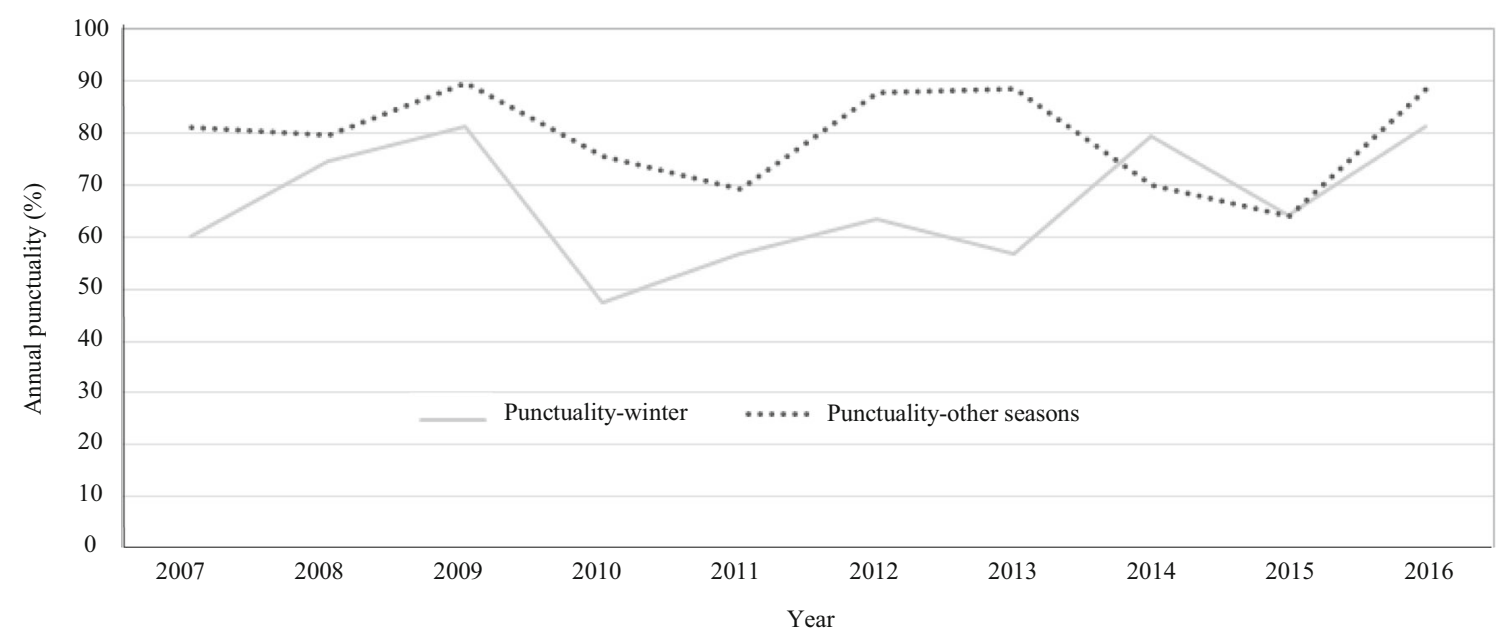

Fig. 4 Annual punctuality in Nordland Line. Data source: Jernbaneverket [16]

We then determined the effect of weather conditions on punctuality of passenger trains using correlation analysis. The correlation coefficient (Pearson product-moment correlation coefficients or Pearson's $r$ ) was used to measure the extent of the relationship between variables, followed by a linear regression analysis. In this study, the measures of punctuality are treated as dependent variables, while the assumed drivers of low punctuality (weather variables) are treated as independent variables. The results of the analysis are described in the following section.

\section{Results}

\subsection{Correlation analysis}

Table 2 shows the correlations between the assumed drivers of low punctuality (our independent variables) that are included in this study using daily weather data. Any value between -1 and 0 indicates negative correlation and between 0 and +1 indicates positive correlation. The results show that several of the independent variables are highly correlated with each other.

Tables 3 and 4 show the Pearson correlation coefficients between punctuality and assumed drivers of low punctuality for the overall period 2007-2016 and individual years, using weekly and daily datasets, respectively.

For the overall period under investigation (2007-2016), the week-by-week absolute value of the correlation between punctuality and different weather variables varies between 0.15 and 0.31 (significant at 0.000 ). The variables attributed to snow depth are shown to have the highest correlation with punctuality, and wind speed variables have the lowest correlation.
In the following, the results are discussed per weather index. The first two rows of Table 3 show the results of a correlation analysis between temperature variables and punctuality. It is observed that the minimum temperature contributed to low punctuality in most of the years; the exceptions are years 2008, 2014 and 2015. The maximum relationship is observed in years 2013 and 2010 with $r$ values (significant at 0.000 ) of 0.44 and 0.42 , respectively. The number of days with temperature below $-15{ }^{\circ} \mathrm{C}$ shows a negative correlation with punctuality which reveals that punctuality decreases as the number of days with cold temperature increases in a week. The exceptions are years 2008 and 2015.

The second three rows of Table 3 are the results of a correlation analysis between snow depth variables and punctuality. It is shown that snow depth variables have a negative relationship with punctuality in most of the years; the exceptions are years 2008 and 2015. Low punctuality attributed to the sum of snow depth correlates more closely in the years 2010, 2012 and 2013 with $r$ values (significant at 0.000 ) of $-0.70,-0.59$ and -0.59 , respectively.

Rows 6 and 7 in Table 3 present the results of the relationship between punctuality and precipitation. Although there is a negative correlation between punctuality and precipitation in most of the years, this correlation is only statistically significant in years 2012 ( $r$ value of -0.46 , significant at 0.000$)$ and 2014 ( $r$ value of -0.26 , significant at 0.05 ).

The last two rows of Table 3 show the results of the correlation between punctuality and wind speed variables. The correlation coefficients for most cases are negative, but only significant in years 2009, 2011, 2012 and 2013. The maximum correlation coefficient is observed between punctuality and wind speed above $10 \mathrm{~m} / \mathrm{s}$ in the year 2013 with an $r$ value of -0.50 (significant at 0.000 ). 


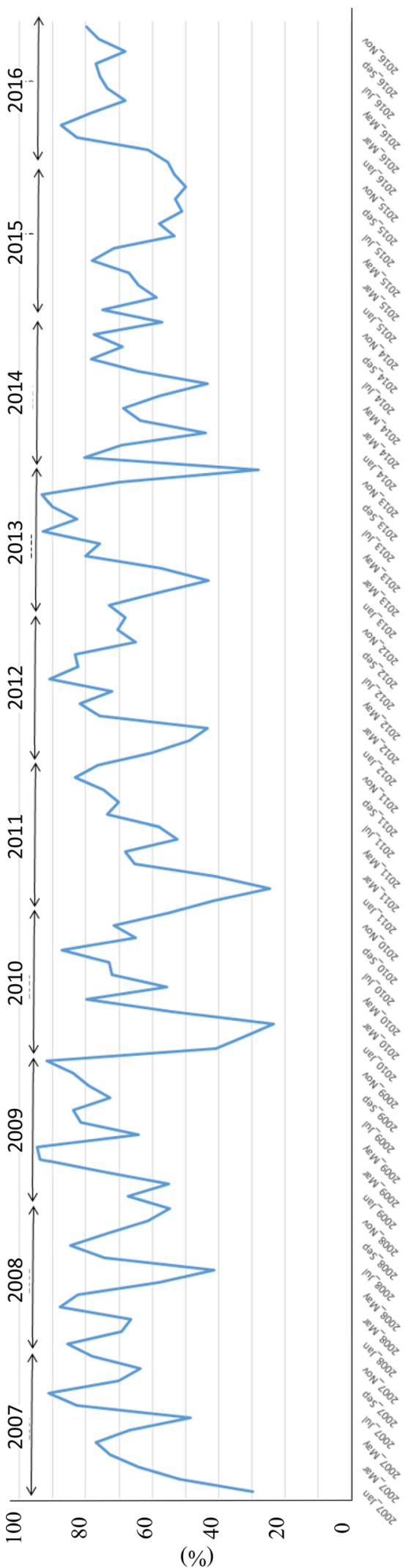

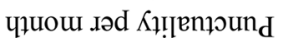

Fig. 5 Punctuality per month for passenger trains in Nordland railway (section between Trondheim and Bodø) from 2007 to 2016

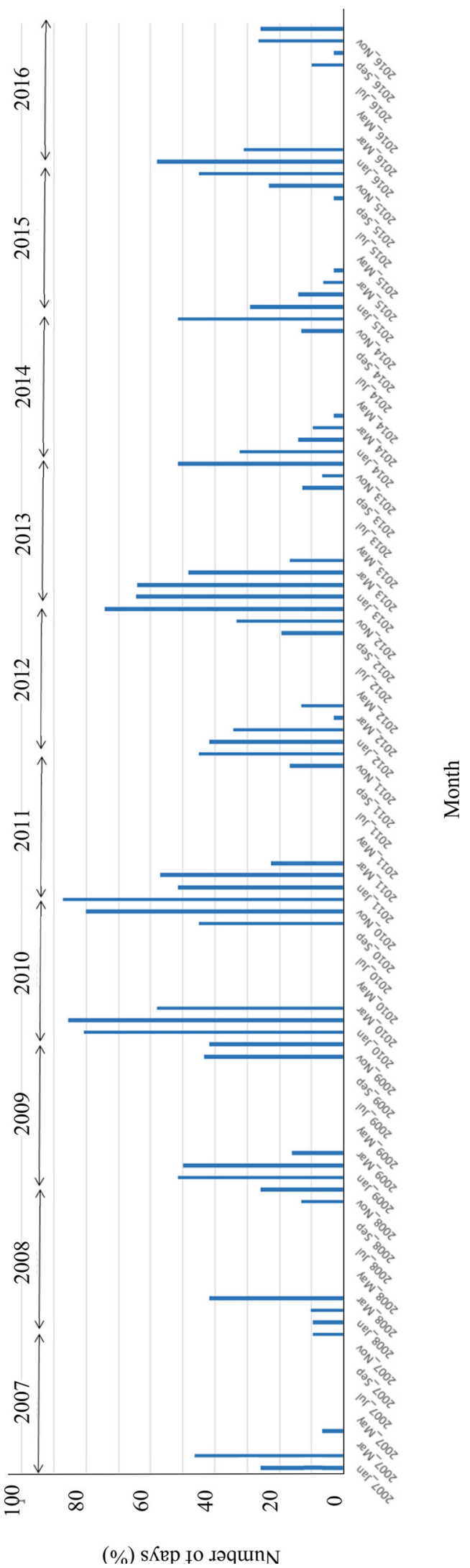

Fig. 6 Number of days (\%) with temperature below $-15{ }^{\circ} \mathrm{C}$ in a month across the Nordland railway network from 2007 to 2016 
Table 2 Pearson product-moment correlation coefficients (Pearson's $r$ ) between assumed drivers of low punctuality.

\begin{tabular}{|c|c|c|c|c|c|c|c|c|c|}
\hline & $\begin{array}{l}\text { Temperature } \\
(\mathrm{min})\end{array}$ & $\begin{array}{l}\text { Temperature } \\
\left(<-15^{\circ} \mathrm{C}\right)\end{array}$ & $\begin{array}{l}\text { Snow } \\
\text { depth } \\
(\max )\end{array}$ & $\begin{array}{l}\text { Snow depth } \\
(>30 \mathrm{~cm})\end{array}$ & $\begin{array}{l}\text { Snow } \\
\text { depth } \\
\text { (sum) }\end{array}$ & $\begin{array}{l}\text { Precipitation } \\
(\max )\end{array}$ & $\begin{array}{l}\text { Precipitation } \\
(>10 \mathrm{~mm})\end{array}$ & $\begin{array}{l}\text { Wind } \\
\text { speed } \\
(\max )\end{array}$ & $\begin{array}{l}\text { Wind speed } \\
(>10 \mathrm{~m} / \mathrm{s})\end{array}$ \\
\hline $\begin{array}{l}\text { Temperature } \\
(\min )\end{array}$ & 1.00 & -0.75 & -0.46 & -0.51 & -0.46 & 0.06 & 0.06 & -0.37 & -0.12 \\
\hline $\begin{array}{l}\text { Temperature } \\
\qquad\left(<-15^{\circ} \mathrm{C}\right)\end{array}$ & -0.75 & 1.00 & 0.24 & 0.29 & 0.26 & -0.06 & -0.06 & 0.04 & 0.03 \\
\hline $\begin{array}{l}\text { Snow depth } \\
\quad(\max )\end{array}$ & -0.46 & 0.24 & 1.00 & 0.88 & 0.96 & 0.06 & 0.04 & 0.28 & 0.21 \\
\hline $\begin{array}{l}\text { Snow depth } \\
\qquad(>30 \mathrm{~cm})\end{array}$ & -0.51 & 0.29 & 0.88 & 1.00 & 0.84 & 0.04 & 0.02 & 0.27 & 0.20 \\
\hline $\begin{array}{l}\text { Snow depth } \\
\quad \text { (sum) }\end{array}$ & -0.46 & 0.26 & 0.96 & 0.84 & 1.00 & 0.07 & 0.06 & 0.27 & 0.20 \\
\hline $\begin{array}{l}\text { Precipitation } \\
\quad(\max )\end{array}$ & 0.06 & -0.06 & 0.06 & 0.04 & 0.07 & 1.00 & 0.77 & 0.24 & 0.20 \\
\hline $\begin{array}{l}\text { Precipitation } \\
\qquad(>10 \mathrm{~mm})\end{array}$ & 0.06 & -0.06 & 0.04 & 0.02 & 0.06 & 0.77 & 1.00 & 0.15 & 0.12 \\
\hline $\begin{array}{l}\text { Wind speed } \\
(\max )\end{array}$ & -0.37 & 0.04 & 0.28 & 0.27 & 0.27 & 0.24 & 0.15 & 1.00 & 0.71 \\
\hline $\begin{array}{l}\text { Wind speed } \\
\quad(>10 \mathrm{~m} / \mathrm{s})\end{array}$ & -0.12 & 0.03 & 0.21 & 0.20 & 0.20 & 0.20 & 0.12 & 0.71 & 1.00 \\
\hline
\end{tabular}

Correlation coefficients that are significant at the 0.01 level or less are marked with bold font

One may argue that using a weekly dataset, which is the product of grouping daily values, may change the real effect of the measures. Therefore, a higher-resolution dataset was used by applying daily values. Table 4 illustrates the correlation coefficients between punctuality and assumed drivers of low punctuality for the corresponding period using daily values. Although there is a large variation in the strength of the correlation coefficients between daily and weekly values, results show a fairly similar trend in which the same factors remain statistically significant at the 0.05 and 0.01 levels.

Applying daily values for the overall period, the correlation coefficients typically have an absolute value of between 0.08 and 0.19 (significant at 0.000). For the overall period, the variables attributed to snow depth are shown to have the highest correlation with punctuality, which is consistent with the results of the correlation analysis for the weekly data. On a year-by-year basis, the highest correlations are also observed between punctuality and snow indicators, the maximum of which happened in the year 2010 for low punctuality attributed to the sum of snow depth with an $r$ value of -0.44 (significant at 0.000 ), followed by an $r$ value of -0.36 (significant at 0.000 ) in 2013 , and an $r$ value of -0.35 (significant at 0.000 ) in 2012. It is noticeable that in comparison with the weekly dataset, the value of the coefficient has decreased. There might be several explanations for this difference. One possible explanation is that fluctuations in punctuality and weather data increase when one considers daily values instead of averages of daily samples as weeks. Weekly data are more aggregated, and the aggregation will compensate for random fluctuations [35]. The correlation coefficients are therefore expected to be lower for daily data than for more aggregated weekly data.

Based on the correlation results in Tables 3 and 4, the highest significant relationship is observed between punctuality and the independent variable, sum of snow depth, in years 2010, 2012 and 2013. It is also found that in years 2008 and 2014, the correlation coefficients become low and statistically insignificant. In 2015, the correlation coefficients for most weather factors are shown to be low and not significant. The only statistically significant result in 2015 belongs to the relationship between punctuality and snow depth which appears as a driver of high punctuality. A plausible explanation for this pattern in the results is that, according to weather data, years 2008, 2014 and 2015 experienced mild winters, while years of 2010, 2012 and 2013 had the coldest winters in the investigated time span 2007-2016. Therefore, it can be said that extreme cold weather during winters is a crucial influencing factor contributing to delays and low punctuality.

\subsection{Linear regression analysis}

To further explore the relationship between punctuality and combined weather factors a linear regression was performed. We performed the regression analysis in the years 2010, 2012 and 2013 which were shown, by the correlation 
Table 3 Pearson product-moment correlation coefficients (Pearson's $r$ ) between punctuality and weather factors using weekly data

\begin{tabular}{|c|c|c|c|c|c|c|c|c|c|c|c|}
\hline Indicator & 2007 & 2008 & 2009 & 2010 & 2011 & 2012 & 2013 & 2014 & 2015 & 2016 & 2007-2016 \\
\hline \multicolumn{12}{|l|}{ Temperature } \\
\hline Min & 0.30 & -0.26 & 0.33 & 0.42 & 0.17 & 0.39 & 0.44 & 0.00 & -0.07 & 0.23 & 0.20 \\
\hline$<-15^{\circ} \mathrm{C}$ & -0.27 & 0.03 & -0.36 & -0.37 & -0.15 & -0.25 & $-\mathbf{0 . 3 0}$ & -0.23 & 0.15 & -0.25 & -0.22 \\
\hline \multicolumn{12}{|l|}{ Snow depth } \\
\hline Max & -0.34 & 0.10 & -0.17 & -0.65 & -0.36 & -0.54 & -0.61 & -0.11 & 0.19 & -0.04 & -0.24 \\
\hline$>30 \mathrm{~cm}$ & -0.35 & 0.13 & -0.21 & -0.62 & -0.36 & -0.42 & -0.55 & -0.14 & 0.25 & 0.00 & -0.23 \\
\hline Sum & -0.41 & 0.11 & -0.31 & -0.70 & -0.35 & -0.59 & -0.59 & -0.15 & 0.18 & -0.10 & -0.31 \\
\hline \multicolumn{12}{|l|}{ Precipitation } \\
\hline $\operatorname{Max}$ & 0.00 & -0.19 & -0.17 & -0.15 & -0.12 & -0.46 & -0.10 & -0.26 & -0.20 & -0.09 & -0.19 \\
\hline$>10 \mathrm{~mm}$ & 0.00 & -0.16 & -0.28 & -0.22 & -0.22 & -0.44 & -0.02 & -0.11 & -0.22 & -0.21 & -0.20 \\
\hline \multicolumn{12}{|l|}{ Wind speed } \\
\hline Max & -0.14 & 0.16 & $-\mathbf{0 . 3 7}$ & -0.03 & -0.36 & -0.36 & -0.46 & 0.03 & -0.07 & 0.05 & -0.16 \\
\hline$>10 \mathrm{~m} / \mathrm{s}$ & -0.17 & 0.07 & -0.40 & -0.13 & -0.29 & -0.21 & -0.50 & 0.08 & -0.14 & 0.05 & -0.15 \\
\hline
\end{tabular}

Correlation is significant at the 0.01 level or less for factors in bold font (two-tailed) and between 0.01 and 0.05 levels (two-tailed) for factors in italic font. Coefficients not significant at the 0.05 level are marked in regular font

Table 4 Pearson product-moment correlation coefficients (Pearson's $r$ ) between punctuality and weather factors using daily data

\begin{tabular}{|c|c|c|c|c|c|c|c|c|c|c|c|}
\hline Indicator & 2007 & 2008 & 2009 & 2010 & 2011 & 2012 & 2013 & 2014 & 2015 & 2016 & 2007-2016 \\
\hline \multicolumn{12}{|l|}{ Temperature } \\
\hline Min & 0.21 & -0.08 & 0.18 & 0.23 & 0.10 & 0.18 & 0.22 & 0.05 & -0.01 & 0.15 & 0.12 \\
\hline$<-15{ }^{\circ} \mathrm{C}$ & -0.20 & 0.00 & -0.18 & -0.21 & -0.08 & -0.16 & -0.23 & -0.12 & 0.00 & -0.11 & -0.11 \\
\hline \multicolumn{12}{|l|}{ Snow depth } \\
\hline Max & -0.23 & 0.05 & -0.12 & -0.40 & -0.24 & -0.32 & -0.37 & -0.06 & 0.08 & -0.01 & -0.14 \\
\hline$>30 \mathrm{~cm}$ & -0.21 & 0.03 & -0.15 & -0.36 & -0.24 & -0.23 & $-\mathbf{0 . 3 3}$ & -0.11 & 0.13 & 0.04 & -0.14 \\
\hline Sum & -0.25 & 0.04 & 0.20 & -0.44 & -0.23 & -0.35 & -0.36 & -0.09 & 0.08 & -0.03 & -0.19 \\
\hline \multicolumn{12}{|l|}{ Precipitation } \\
\hline $\operatorname{Max}$ & 0.01 & 0.03 & -0.07 & -0.10 & -0.10 & -0.20 & -0.10 & -0.20 & -0.10 & -0.01 & -0.09 \\
\hline$>10 \mathrm{~mm}$ & 0.06 & 0.02 & -0.10 & -0.09 & -0.08 & -0.18 & -0.10 & -0.14 & -0.06 & -0.07 & -0.08 \\
\hline \multicolumn{12}{|l|}{ Wind speed } \\
\hline Max & -0.01 & 0.00 & -0.11 & 0.03 & -0.15 & -0.06 & -0.12 & -0.05 & -0.11 & -0.08 & -0.08 \\
\hline$>10 \mathrm{~m} / \mathrm{s}$ & -0.02 & -0.06 & -0.08 & 0.00 & -0.15 & -0.03 & -0.16 & 0.00 & -0.08 & -0.01 & -0.08 \\
\hline
\end{tabular}

Correlation is significant at the 0.01 level or less for factors in bold font (two-tailed) and between 0.01 and 0.05 levels (two-tailed) for factors in italic font. Coefficients not significant at the 0.05 level are marked in regular font

analysis, to be more influenced by weather factors compared to other years in the period 2007-2016. Since the independent variables were shown not to be independent of each other (Table 2), including all variables in the multiple regression model, can result in the occurrence of multicollinearity, which further increases the standard errors of the coefficients and leads to skewed results [36]. To avoid the problem of multicollinearity in the regression model, we defined a variance inflation factor (VIF) of 5 as a cut-off value [37] and included the independent variables which had a correlation of less than 0.8 with other independent variables. Therefore, we selected one variable from each category of weather factors. The results of the regression analysis are presented in Table 5.

The regression model using a weekly dataset resulted in significant regression fits $\left(R^{2}\right)$ of $0.55,0.47$ and 0.48 for the 
Table 5 Regression models for punctuality

\begin{tabular}{|c|c|c|c|c|c|c|}
\hline & \multicolumn{3}{|l|}{ Weekly data } & \multicolumn{3}{|l|}{ Daily data } \\
\hline & 2010 & 2012 & 2013 & 2010 & 2012 & 2013 \\
\hline Constant & $0.733 * * *$ & $0.788 * * *$ & $1245 * * *$ & $0.702 * * *$ & $0.764 * * *$ & $0.944 * * *$ \\
\hline Temperature (min) & 0.000 & 0.006 & -0.086 & 0.001 & 0.004 & 0.001 \\
\hline Snow depth (sum of $\mathrm{cm}$ ) & $-0.002 * * *$ & $-0.001 * * *$ & $-0.782 * *$ & $-0.002 * * *$ & $0.004 * * *$ & $-0.001 * *$ \\
\hline Precipitation (max) & $-0.015^{*}$ & $-0.014^{* *}$ & -59.950 & $-0.006^{*}$ & $-0.001 * *$ & $-0.005^{*}$ \\
\hline Wind speed (max) & 0.022 & 0.023 & $-3.632 * *$ & 0.014 & 0.019 . & -0.009 \\
\hline$R^{2}$ & 0.55 & 0.47 & 0.48 & 0.22 & 0.16 & 0.15 \\
\hline
\end{tabular}

Variables statistically significant at the 0 level are marked by a triple asterisk (***), variables statistically significant at the 0.001 level are marked by a double asterisk $(* *)$, variables statistically significant at the 0.01 level are marked by a single asterisk $(*)$, variables statistically significant at the 0.05 level are marked by a dot (.)

years 2010, 2012 and 2013, respectively. The fits of the regression models for the daily dataset are lower than those of the models for the weekly dataset. Based on the results, it can be said that, in years with severe cold weather, up to $55 \%$ of the variation in punctuality can be explained by this model. Using daily data, up to $22 \%$ of the variation can be explained by this model. However, when we look closer at the multiple regression results, it is found that every model includes the variable, sum of snow depth, significant at the 0 level, and the effect of snow depth in all models explains most of the variance. We also used a model in which only statistically significant variables were included and the predicting variables were removed step by step based on their p-value. We ended up in a regression model including only the predicting variable, sum of snow depth, using a weekly dataset. This model resulted in $R^{2}$ of $0.51,0.42$ and 0.43 for the years 2010, 2012 and 2013, respectively, which is only slightly lower than those of the models including four weather variables. This implies that the main weather variable that best explains variations in punctuality of passenger trains is snow depth, while the other variables have less effect on punctuality.

\section{Discussion}

Pearson's correlation and linear regression results in this study found that very cold weather is one of the drivers of low punctuality of trains, which is in line with the findings in our previous research from urban commuter traffic in winter conditions [33]. This indicates that by managing cold winters, the chances of having punctual trains can be significantly increased.

While both low temperature and deep snow correlate with poor punctuality, we found that snow depth was the strongest predictor of low punctuality for the Nordland Line. It is interesting to compare these results with the similar study of [33]. That study found that for local urban trains, there was a stronger correlation between poor punctuality and low temperature than between poor punctuality and deep snow. This indicates that for urban commuting trains, low temperature is a relatively bigger challenge than snow, while for long-distance passenger trains, snow depth is a relatively bigger challenge. One possible explanation is that urban trains in the Oslo area pass through a relatively large number of tunnels. Temperature inside long tunnels is higher than outside, and frequently above zero degrees centigrade. As a consequence, snow and ice start melting, but freezes again when exiting the tunnel, especially if it is very cold outside the tunnel. The melted snow and ice freeze and form solid ice, which typically is a larger problem to the rolling stock and infrastructure than snow. Ice falling off trains can get stuck in switches, and it takes longer time to melt solid ice than snow. In contrast to the Oslo area, the Nordland Line has only one long tunnel, located in the southern end of the line. Ice and snow melting in tunnels are therefore not a likely issue on the line we have studied in this paper. Snow seems to be a bigger issue. In particular, the areas above the tree line are also exposed to wind and drifting snow.

It is important to point out that in the years following the winter of 2010, the number of winter-related actions has increased significantly to handle the effects of weather elements on Norwegian railways and increase the efficiency of the infrastructure network [38]. These improvements include the addition of extra capacity for removal of snow at strategically important parts of the infrastructure, especially at switches, and installing electric heating for switches and crossings. However, the results show that in the years 2012 and 2013, which were the coldest after the winter of 2010, punctuality has still been highly affected by snowy and cold weather.

The development of winterization measures and adjustments of operation procedures within the whole 
railway network has been constantly ongoing. Another large improvement process, including better maintenance work and winter management, has been developed for the Nordland Line since 2014 in order to make the railway more robust against climate challenges [39]. The research on visualization of punctuality data [40] contributes to the identification of such actions. There are also larger investments in new tracks, especially in the southern part of the line which has the most traffic. Ongoing maintenance actions to improve punctuality on the line include replacement and cleaning of ballast, adjustments of track and switches, and replacement of sleepers [41].

It is also important for the infrastructure and train operators to be aware of weather forecasts for extreme weather conditions. As a consequence, the infrastructure manager Jernbaneverket (now Bane NOR) has invested in their own weather monitoring stations, located at prioritized positions along the railway line. Eight of these are located on the Nordland Line [42]. One major reason for setting up these weather monitoring stations is the expected increase in extreme weather due to climatic change [43]. In relation to extreme weather, punctuality is important, but it is even more important to avoid major damages on the railway line, which may cause that the line closes for longer periods. Such closings are particularly damaging to the railway's reputation. For example, at the time of writing, the Nordland Line was closed for 5 days from April 22 because large amounts of water from melted snow washed away several metres of the railway substructure in the north of Mosjøen. The snow melting season in the spring is exposed for such long-lasting disruptions. Consequently, the infrastructure manager is presently reinforcing the substructure of the line on selected locations to make the line more robust [41]. In addition, systems have been installed to improve notification to train drivers if wildlife is observed along the railway line.

The Nordland Line has not recently experienced winters as cold as those in the years 2010, 2012 and 2013. As a consequence, we do not really know to what extent winterrelated actions have improved railway operations to be able to manage the full variety of winter conditions that this line is exposed to.

The presented study is, to a certain extent, a replication of previous studies of how weather conditions affect train operations. However, the studied railway line is continuously exposed to more challenging winter conditions than what is the case for most of the previous studies. In addition, replication studies contribute to the knowledge and scientific rigour of any scientific discipline. This type of replication studies on delay factors, in this case winter weather factors, can hopefully contribute to reliable knowledge about railway operations and increased scientific rigor in the field.

\section{Conclusion and future work}

We studied the relationship between weather variables and punctuality of passenger trains on the Nordland railway line. Pearson correlation and multiple regression approaches were used for this purpose. The results of this research clearly indicate that the extent to which the weather factors have influenced the punctuality of passenger trains on the Norwegian railway varies in different years. Weather factors affect punctuality to a greater extent in years with harsh winters compared to years with milder winters. Only during winters that are mild do rail operations perform in line with, or better than, the norm for the rest of the year. Therefore, it can be said that very cold weather during winters is a crucial driver of delays and low punctuality of trains. We also found that the main weather variable that best explains the daily and weekly variations in the punctuality of passenger trains is snow depth and the other variables have less effect on punctuality.

This study partially supports the assumption that weather is an important influencing factor contributing to delays and low punctuality. A considerable part of the variance is still unexplained and depends on factors other than weather. This unexplained variance should therefore be explored in future studies. Moreover, the focus of this study was mainly on passenger trains on the Nordland Line. In future research, it is worth performing similar investigations on other types of train services as well as considering other regions exposed to different weather characteristics.

Acknowledgements The authors would like to thank Andreas D. Landmark who kindly assisted by providing punctuality data.

Open Access This article is distributed under the terms of the Creative Commons Attribution 4.0 International License (http:// creativecommons.org/licenses/by/4.0/), which permits unrestricted use, distribution, and reproduction in any medium, provided you give appropriate credit to the original author(s) and the source, provide a link to the Creative Commons license, and indicate if changes were made.

\section{References}

1. Veiseth M, Magnus Hegglund P, Wien I, Olsson NO, Stokland Ø (2011) Development of a punctuality improvement method. TQM J 23(3):268-283

2. Harris NG, Mjøsund CS, Haugland H (2013) Improving railway performance in Norway. J Rail Transp Plann Manag 3(4): $172-180$

3. Norheim B, Ruud A (2011) The underestimated demand for public transport? In: European transport conference 2011

4. Harris N, Haugland H, Olsson N, Veiseth M (2016) An introduction to railway operations planning. A \& N Harris, London 
5. Ludvigsen J, Klæboe R (2014) Extreme weather impacts on freight railways in Europe. Nat Hazards 70(1):767-787

6. Johnson T (1996) Strong; wind effects on railway operations16th October 1987. J Wind Eng Ind Aerodyn 60:251-266

7. Baker CJ, Chapman L, Quinn A, Dobney K (2010) Climate change and the railway industry: a review. J Mech Eng Sci 224(3):519-528

8. Doll C, Trinks C, Sedlacek N et al (2014) Adapting rail and road networks to weather extremes: case studies for southern Germany and Austria. Nat Hazards 72(1):63-85

9. Palmqvist CW, Olsson NOE, Hiselius L (2017) Delays for passenger trains on a regional railway line in southern Sweden. Int $\mathrm{J}$ Transp Dev Integr 1(3):421-431

10. Parbo J, Nielsen OA, Landex A, Prato CG (2013) Measuring robustness, reliability and punctuality within passenger railway transportation: a literature review. www.trafikdage.dk/abstracts_ 2013/168_JensParbo.pdf. Accessed February 14, 2018

11. Hansen IA (2001) Improving railway punctuality by automatic piloting. In: Proceedings of IEEE intelligent transportation systems, IEEE, pp 792-797

12. Olsson NO, Haugland $\mathrm{H}$ (2004) Influencing factors on train punctuality-results from some Norwegian studies. Transp Policy 11(4):387-397

13. Vromans MJ, Dekker R, Kroon LG (2006) Reliability and heterogeneity of railway services. Eur $\mathrm{J}$ Oper Res 172(2):647-665

14. Nicholson GL, Kirkwood D, Roberts C, Schmid F (2015) Benchmarking and evaluation of railway operations performance. J Rail Transp Plann Manag 5(4):274-293

15. Olsson N, Halse AH, Hegglund PM, Killi M, Landmark AD, Seim AR, Sørensen AØ, Økland A, Østli V (2015) Punktlighet i jernbanen-hvert sekund teller. SINTEF Viten. https://www. sintefbok.no/book/index/1055/punktlighet_i_jernbanen_hvert_ sekund_teller. Accessed $11 \mathrm{Feb} 2018$

16. Jernbaneverket (2015a). Jernbanestatistikk 2015. http://www. jernbaneverket.no/Om-oss/Arsmeldinger-og-rapportar-fraJernbaneverket/jernbanestatistikk-2015. Accessed 20 July 2017

17. Brazil W, White A, Nogal M, Caulfield B, O'Connor A, Morton C (2017) Weather and rail delays: analysis of metropolitan rail in Dublin. J Transp Geogr 59:69-76

18. Diab E, Shalaby A (2017) Rail transit resilience: understanding the impacts of outdoor tracks and weather conditions on subway system interruptions (No. 17-06586)

19. Palmqvist C-W, Olsson N, Hiselius L (2017b) Some influencing factors for passenger train punctuality in Sweden. Int J Progn Health Manag 8 (Special Issue on Railways and Mass Transportation, 020:13

20. Xu P, Corman F, Peng Q (2016) Analyzing railway disruptions and their impact on delayed traffic in Chinese high-speed railway. IFAC-Pap Online 49(3):84-89

21. Nagy E, Csiszár C (2015) Analysis of delay causes in railway passenger transportation. Period Polytech Transp Eng 43(2):73

22. Jaroszweski D, Hooper E, Baker C et al (2015) The impacts of the 28 June 2012 storms on UK road and rail transport. Meteorol Appl 22(3):470-476

23. Mesbah M, Lin J, Currie G (2015) "Weather" transit is reliable? Using AVL data to explore tram performance in Melbourne, Australia. J Traffic Transp Eng 2(3):125-135 (English Edition)

24. Xia Y, Van Ommeren JN, Rietveld P, Verhagen W (2013) Railway infrastructure disturbances and train operator performance: the role of weather. Transp Res Part D Transp Environ 18:97-102
25. Tsapakis I, Cheng T, Bolbol A (2013) Impact of weather conditions on macroscopic urban travel times. J Transp Geogr 28:204-211

26. Juntti U (2012) Impact of climate on railway operation: a Swedish case study. In: International heavy Haul association conference: 19/06/2011-22/06/2011. International Heavy Haul Association

27. Stenström C, Famurewa SM, Parida A, Galar D (2012) Impact of cold climate on failures in railway infrastructure. In: International conference on maintenance performance measurement and management: 12/09/2012-13/09/2012

28. Thornes JE, Davis BW (2002) Mitigating the impact of weather and climate on railway operations in the UK. In: Railroad conference, 2002 ASME/IEEE joint, IEEE, pp 29-38

29. Riksrevisionsverket (1986) Tågtrafikens punktlighet', Revisionsrapport, Dnr. 1986:1091

30. Tahvili N (2016) Winterization of Railways-Issues and Effects. In: Master's Thesis, NTNU

31. Bettez M, Olsson N (2011) Winter technologies for high speed rail. In: Master's Thesis, Norwegian University of Science and Technology, Trondheim

32. Olsson N, Økland A, Veiseth M, Stokland Ø (2010) Driftsstabilitet på Jernbaneverkets nett-årsaksanalyser 2005-2010: punktlighets-og regularitetsutviklingen, gransking av årsaker. In: SINTEF Report no A15731. SINTEF Technology and Society, Trondheim, https://www.sintef.no/globalassets/upload/konsern/ media/rapport-jernbane.pdf. Accessed 11 Feb 2018

33. Zakeri G, Olsson NOE (2017) Investigation of punctuality of local trains: the case of Oslo area. Transp Res Proced 27:373-379

34. eKlima (2017) http://eklima.met.no. Accessed 20 July 2017

35. Krewinkel BC (2014) A correlation study between climate indexes and high runoff events in the Lanjiang River basin, China. In: Bachelor's Thesis, University of Twente

36. Hair JF, Black WC, Babin BJ et al (1998) Multivariate data analysis, vol 5(3), Upper Saddle River, Prentice hall, pp 207-219

37. Kutner MH, Nachtsheim CJ, Neter J (2004) Applied linear regression models, 4th edn. McGraw-Hill Irwin, Boston

38. Jernbaneverket (2015b) On track: glimpses of jernbaneverkets activities in 2015. http://www.banenor.no/contentassets/ 3279c389ae78493793ebaf3592f493d2/on-track-2015-glimpsesof-jernbaneverkets-activities.pdf. Accessed 20 July 2017

39. Jernbaneverket (2014) On track: glimpses of jernbaneverkets activities in 2014. http://www.banenor.no/contentassets/ 3279c389ae78493793ebaf3592f493d2/on-track-2014.pdf. Accessed 20 July 2017

40. Landmark AD, Seim AA, Olsson N (2017) Visualisation of train punctuality : illustrations and cases. Transp Res Proc 27:1227-1234

41. BaneNor (2017) Vedlikeholdsoversikt 2017. http://www.banenor. no/Nyheter/Togenes-punktlighet-og-regularitet/ punktlighetstiltak-og-vedlikeholdsoversikt-2017/ vedlikeholdsoversikt-2017. Accessed 14 May 2018

42. Kjøsnes G (2015) Suksessfaktorer ved utbygging av små byggeprosjekter for Jernbaneverket i en kompleks kontekst, illustrert i prosjektet om målestasjoner for værdata. Master's thesis, Trondheim: Norwegian University of Science and Technology

43. Ministry of Transport and Communications (2013) National transportation plan 2014-2023. Meld. St. 26 (2012-2013) 